\title{
Editorial: Fury and Technique
}

'When a man with two talents chooses (or at any rate concentrates upon) one, he may look sourly on the practitioners of the other.' Iris Murdoch is a woman with two talents, and this remark may contain a hint of autobiography when it occurs in her Romanes Lecture, The Fire and the Sun: Why Plato Banished the Artists. Like Tolstoy and Plato before her Miss Murdoch is externalizing an inner conflict when she fights on both sides in 'the ancient quarrel between poetry and philosophy'. We already knew from The Sovereignty of Good that she looked critically, though never sourly, on some of her philosophical contemporaries. Their limitations are due in some cases to a lack of literary education and experience, and in other cases to anxiety or shame about an exclusively or excessively literary education. Some members of this last group are liable to be even more determined than the sincerely unlettered to prove the toughness of their minds, and to think that only a tender mind would be sensitive to the informal subtleties of literature and the arts and religion. Plato himself set up the understanding of the mathematician as a mark for all other thinkers to aim at, and castigated the poets for failing to reach it. But at least his complaint carried the correct implication that the poets were attending to subjects and problems of high importance. Their techniques were inadequate and their conclusions were perverse. These faults were serious precisely because their questions and objectives made them rivals to Plato in his own undertaking to find and tell the truth about man and society and God and the world.

Iris Murdoch knows as well as Plato knew how easily the artist can falsify, how treacherous is the self that seeks expression and assertion in images and words:

The imagination fuses, but in order to do so it must tease apart in thought what is apart in reality, resisting the facile merging tendencies of the obsessive ego. The prescription for art is then the same as for dialectic: overcome personal fantasy and egoistic anxiety and selfindulgent day-dream. Order and separate and distinguish the world justly. Magic in its unregenerate form as the fantastic doctoring of the real for consumption by the private ego is the bane of art as it is of philosophy. Obsession shrinks reality to a single pattern. The artist's worst enemy is his eternal companion, the cosy dreaming ego, the dweller in the vaults of eikasia. Of course the highest art is powered by the force of an individual unconscious mind, but then so is the highest philosophy; and in both cases technique is useless without divine fury. 
But she also recognizes more clearly and fully than Plato did that nothing can misrepresent unless it can also represent, that consciousness of failure may be the beginning of success in achieving insight and its communication, and hence that the arts can make their own contribution to the revelation of truth and goodness:

One might, in praising art to Plato, even add that if there is, as an effective persuasion, an ontological proof (Plato's main idea after all), art provides a very plausible version of it. Perhaps in general art proves more than philosophy can. Familiarity with an art form and the development of taste is an education in the beautiful which involves the often largely instinctive, increasingly confident sorting out of what is good, what is pure, what is profoundly and justly imagined, what rings true, from what is trivial or shallow or in some way fake, self-indulgent, pretentious, sentimental, meretriciously obscure, and so on. Most derogatory critical terms impute some kind of falsehood, and on the other hand (Keats) 'what the imagination seizes as beauty must be truth'. Bad art is a lie about the world, and what is by contrast seen as good is in some important evident sense seen as $i p s o$ facto true and as expressive of reality: the sense in which Seurat is better than Burne-Jones, Keats than Swinburne, Dickens than Wilkie Collins, etc., etc.

What she has seen by standing on Plato's shoulders is shown at its clearest when we attend to a theme that has increasingly preoccupied her in fiction and drama as well as in her philosophical writings: what she calls in $A$ Word Child, as well as in this book, jumble-the untidiness of human life and the human world. Both those who aspire after scientific or philosophical understanding and those who aspire after salvation are tempted to seek-and hence too often to think that they have found-a pattern or picture that is clear and simple and at the same time faithful to the facts and values that need to be taken into account. Plato and Miss Murdoch, like all poet-philosopher-priests, seek both understanding and salvation, and like all those who are worth reading and hearing they seek the salvation through the understanding. The difference is that he could not envisage salvation as consisting in any vision less clear or complete than that achieved by the geometer with his Q.E.D., while she knows that even an individual life or character or event may need for its just representation the tortuousness of thought and speech and variegations of tone and colour that the hot gospeller of scientific rationalism associates only with obscurity and mystification.

Jumble is not the same thing as muddle. To be muddled in one's effort to represent is different from representing what is muddled. Turner painted fogs but was not a foggy painter. Mystification is a danger that threatens the artist and the moralist and any philosopher who sympathizes with their 
purposes. Likewise, or conversely, it has been clear from Democritus and Lucretius to The Grammar of Science and Language Truth and Logic that nets with large square meshes are not always the best means of getting truth from the bottom of a well. There is more than one kind of fury, and no end to the resources of technique. 